\title{
Mediation and the Best Interests of the Child from the Child Law Perspective
}

\author{
Kirsikka Salminen
}

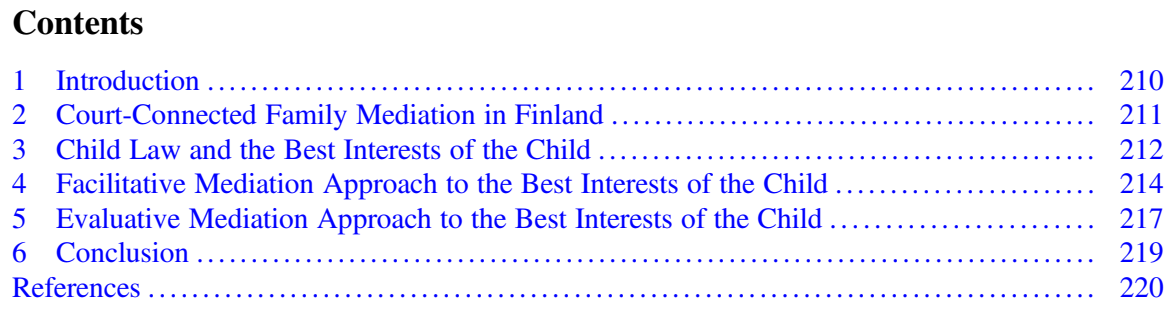

\begin{abstract}
What is the best interests of the child in family mediation and is mediation in the best interests of the child? In this article, I use child law and the United Nations Convention on the Rights of the Child combined with mediation theory to discuss these questions. Both mediation and the best interests of the child are open for multiple interpretations. Using facilitative and evaluative mediation theory and the legal concept 'the best interests of the child', I explore and compare the understandings of these concepts as they apply to family mediation. This includes a discussion of the advantages and disadvantages of facilitative as well as evaluative mediation orientations in terms of protecting the best interests of the child. Finnish courtconnected family mediation is a combination of both mediation orientations, and the mediator is obliged to secure the best interests of the child. From a theoretical point of view, this seems to be a challenging combination.
\end{abstract}

\footnotetext{
K. Salminen ( $\bowtie)$

Faculty of Law, University of Helsinki, Helsinki, Finland

e-mail: kirsikka.salminen@helsinki.fi
} 


\section{Introduction}

During the past decades society at large has increasingly recognised the subjective legal rights of children. Also, the modern child law perspective has been born (see more on this concept below). Simultaneously, various applications and use of mediation as an alternative to court litigation in child custody disputes has increased. In Finland, court-connected family mediation is one application of mediation. Finnish court-connected family mediation is based on two mediation approaches: it is primarily facilitative with some evaluative elements included. The best interests of the child is according to national legislation and the United Nations Convention on the Rights of the Child (UNCRC), the primary consideration in actions concerning children, such as court-connected family mediation in child custody disputes. The best interests of the child is, however, a complex term that can be approached from various disciplines. The child law perspective is one way to view the requirements set for mediation by the best interests of the child. ${ }^{1}$

This article focuses on two mediation approaches: facilitative and evaluative mediation and explores how do these orientations (approaches) support the best interests of the child from a child law perspective. My aim is not to present one mediation model as favourable over the other or to discuss the purposes mediation is developed for but rather to shed the light of child law perspective on these two mediation approaches.

In this article, the facilitative and evaluative mediation, as well as the best interests of the child, are anchored to certain definitions that are compared with each other. The aim is also to problematise and open for discussion the operation of the best interests of the child and its elements in mediation. The context in this article is Finnish, but the idea of mediation models and the child law perspective are international. This article is partly based on a larger research project that is focused on Finnish court-connected family mediation and, thus, the Finnish context is shortly presented here, too.

This article combines legal doctrine, especially the child law perspective, with conflict and mediation theories through comparing these systems with each other. Legal rights discussion focuses on legal rights and promotes legal security. The mediation discussion focuses on conflicts, communication, interests, needs and agreements.

\footnotetext{
${ }^{1}$ The author is conducting doctorate research on this topic in Finland with law and mediation theory based approach and qualitative empirical data. This article is loosely based on the theoretical and non-empirical sections of the yet unpublished dissertation.
} 


\section{Court-Connected Family Mediation in Finland}

In Finland, a country about 5.5 million inhabitants, every year about 30,000 children go through their parents separation. About $90 \%$ of all divorcing or separating families solve child custody and contact issues without court proceedings. In about every tenth separated family the conflict escalates (about the numbers, OM 25/2013). In the Nordic countries, about $10 \%$ of all child custody disputes are brought to court (Ervasti and Nylund 2014). In Finland, the court proceedings are either litigation, where the outcome is either a judgment or agreement, or court-connected mediation. In 2014, about 800 cases went to court-connected family mediation (Salminen and Ervasti 2015).

In Finland, the parents have the right to agree on child custody and contact right but best interests standard limits their choices. This need for evaluation by the authorities brings a certain tension to mediation, since party self-determination ${ }^{2}$ is typically seen as the core element of mediation (Welsh 2004; Bush and Folger 2005; Shienvold 2004; Roberts 2008; Ervasti and Nylund 2014; Nylund 2016). Also, the neutral, objective and non-authoritative role of mediator is seen as incompatible with need to secure the best interests of the child (Ervasti and Nylund 2014).

In Finland, the court-connected family mediation is a public service offered by the courts and voluntary for the parties to participate. Also, out-of-court mediation is available for families in Finland (Haavisto 2018). Court-connected family mediation is thus only one of many mediation models and practices in Finland. In this article, the focus is limited to this one specific mediation.

Court-connected mediation is an alternative to litigation in the court to resolve disputes and make arrangements (HE 114/2004 vp). The process is regulated in the Act on mediation in civil matters and confirmation of settlements in general courts (Mediation Act 394/2011, laki riita-asioiden sovittelusta ja sovinnon vahvistamisesta yleisissä tuomioistuimissa). The Act on Child Custody and Right of Access (The Child Custody Act 361/1983, laki lapsen huollosta ja tapaamisoikeudesta) regulates the legal substance of child custody and contact right.

Finnish court-connected family mediation is built on facilitative and evaluative mediation orientations (HE 114/2004 vp, Ervasti 2011). ${ }^{3}$ In the Mediation Act, the objective of mediation is an amicable resolution of the matter (section 3 ). The mediator shall assist the parties in their efforts to reach agreement and an amicable resolution. On the request or with the consent of the parties, the mediator may make a proposal for an amicable resolution. The proposal may be based on what the mediator deems appropriate in view of what the parties have brought forward in the mediation (section 7). Finnish court-connected family mediation has thus a problem solving perspective to mediation (Ervasti and Nylund 2014). It also

\footnotetext{
${ }^{2}$ Self-determination has many aspects. One central element is the party's informed consent that builds on sufficient amount of information in order to promote understanding and free and wellgrounded decision making, see Nolan-Haley (1999).

${ }^{3}$ For the concepts of facilitative and evaluative mediation, see Riskin (1996).
} 
includes elements of legal decision making, since the agreement between the parties can be made legally enforceable by the mediator (sections 8 and 9). The mediator has to evaluate, to some extent, the outcome so that the agreement is not breaching the law or a third party's rights, which is a prerequisite stated in the Mediation Act section 8. To what extend mediators evaluate the agreements is unclear.

The best interests of the child gives family mediation a special goal. In the Finnish court-connected family mediation the mediator is obliged by law to secure that the process and the resolution are in the best interests of the child (the Mediation Act section 10 with reference to the Child Custody Act, especially section 10). According to the preparatory work and the reports of the Ministry of Justice in Finland, mediation safeguards the best interests of a child when the conflict in the child's growth environment is diminished and there is an alternative to a full-scale court trial (HE 114/2004, OM 25/2013, see also Auvinen 2006; Aaltonen 2000, 2015). Internationally and in Finland, too, the negative effects of the parent's continuous conflict on children are recognised (McIntosh et al. 2008; Parkinson 2011; Skjørten 2005; Mueller-Johnson 2005; Johnston et al. 2009; Rejmer 2003; Karttunen 2010; Sinkkonen 2011). Due to their internal conflict, new family structures or, for example, lack of sufficient information, the parents may be ignorant to the needs, interest and rights of their child.

In Finnish court-connected family mediation the mediator is a district court judge. The judge-mediator is assisted by an expert mediator. The expert mediator in childcustody disputes is a social worker, psychiatrist or psychologist specialised in divorcing families and child development psychology. Legal, as well as social and psychological experts, are thus present in mediation.

In theory, Finnish court-connected family mediation can be classified as childinformed, child-focused and child-inclusive mediation, since the law focuses on the best interests of the child and makes child participation possible (see Taylor 2002; Ervasti and Nylund 2014; Parkinson 2011; McIntosh 2000; McIntosh et al. 2008; Saposnek 2004, in Finland also Aaltonen 2015). In practice, child participation in Finnish court-connected family mediation is not typical (the child participates in about $2 \%$ of mediations, according to OM 25/2013.) The child is not a party of the custody-proceedings in national legislation. In mediation, the child is not represented in the process other than through his or her parents (or other person having the custody).

\section{Child Law and the Best Interests of the Child}

Child law is interested in what are the legal rights of the child and how do they appear in various fields of society, systems, processes and life (Freeman 2012a). Child law has been called as an umbrella perspective that can cover all the other fields of law (Bendiksen and Haugli 2014). The more traditional understanding of child law focuses on the child's family relations and objective perspectives on the best interests of the child. During the past few decades, the perspective has turned to the subjective legal rights of children within family and society (Hakalehto-Wainio 
2013). The focus in modern child law is protecting the child's legal rights instead of only protecting the child (Freeman 2012b; Hakalehto-Wainio 2013; Nieminen 1992; Parkinson and Cashmore 2008; Pajulammi 2014; Gottberg 2006).

Today's children have subjective legal rights. The United Nations Convention on the Rights of the Child (UNCRC) is in Finland on top of the legal hierarchy of child's rights (Kangas 2013; Hakalehto-Wainio 2013; Toivonen 2017). Many of the child's rights are also confirmed in the national legislations of the Nordic countries and also in EU legislation. Today the child law perspective is one important element in Finnish court-connected family mediation since Finland, like most of the counties in the world, are bound to the UNCRC's mandate to fulfil the legal rights that belong to children. The rights-based child law perspective thus sets special requirements for family mediation.

According to the UNCRC article 3, in all actions concerning children, the best interests of the child shall be a primary consideration. According to the Committee on the Rights of the Child (CRC), the best interests of a child assessment should be carried out with full respect for the rights contained in the UNCRC and its optional protocols. In addition, the best interests of a child should be evaluated on a case-bycase basis and adjusted to the needs of the specific child in question, since children are not a homogenous group (CRC General Comment 14; CRC General Comment 12). Standard information about children's wellbeing, experiences and participation may not always be the key to reach the best interests of a child in individual cases.

The expression "primary consideration" in article 3 of the UNCRC means that the best interests of the child is not on the same level as all other considerations. The strong position of the best interests of the child is justified, since children are legally in special situation (CRC General Comment 14). Children are under guardianship of adults and have limited ability to act legally. Children are thus dependent on adults' behaviour. Through paying attention to the legal rights of the child, we pay attention to and respect the child as an individual human being with human rights.

According to the CRC "the full application of the concept of the child's best interests requires the development of a rights-based approach, engaging all actors, to secure the holistic physical, psychological, moral and spiritual integrity of the child and promote his or her human dignity" (CRC General Comment 14). In Finland, Toivonen has stated that the child's rights are legally binding and the ignorance leads to breach of the child's human rights (Toivonen 2017).

From the child law perspective, the best interests assessment should follow two steps. The first step is to within the specific factual context find out what are the relevant elements, give them concrete content and assign a weight to each in relation to one another. The second step is to follow a procedure that ensures legal guarantees and proper application of the right. The assessment is individual, the decision maker carries it out and it requires the participation of the child (CRC General Comment 14). Concrete examples of the best interests assessment in mediation are given later in the text.

The best interests of the child should be viewed individually and on a case-bycase basis. Even though all the rights should have independent value, the elements of the best interests assessment may be in conflict with each other and in certain 
circumstances. Not all elements are relevant in every case, and different elements can be used in different ways in different cases. In weighing the various elements the purpose of the assessment should be bared in mind: to ensure the full and effective enjoyment of the rights recognised in the UNCRC and the holistic development of the child (CRC General Comment 14).

According to the CRC, the decision maker is obliged to secure the fulfilment of the best interests of the child. Further, it is stated that the obligation to have the best interests of a child as a primary consideration applies to mediation, too (CRC General Comment 12; CRC General Comment 14). From the perspective of the mediation theories one can, however, ask who has the obligation to fulfil the best interests of the child, since the parties' self-determination is a central element of mediation and the mediator should not have an authority to decide the case. Facilitative and evaluative mediation have somewhat differing approaches to this question, and the approaches are presented later in the text.

The child law perspective has been incorporated into family mediation. The best interests of the child and the child's legal right to participate have been recognised and child-informative, child-focused, and child-inclusive mediation have been developed (see McIntosh 2000; McIntosh et al. 2008; Roberts 2008; Parkinson 2011). The following chapters focus on how the traditional facilitative and evaluative mediation orientations can reflect the rights-based best interests assessment.

\section{Facilitative Mediation Approach to the Best Interests of the Child}

Approaches to and ways to define mediation are today many (see Ervasti and Nylund 2014). One way to systematise approaches to mediation is the perspective of facilitative and evaluative orientations (presented by Leonard Riskin at the turn of the century (see Riskin 1996, 2003). ${ }^{4}$ After the Riskin's grid, the orientations and approaches have been developed further and defined with various points emphasised. They have been criticised, as well. The dichotomy has thus had an important impact in the field of mediation and has landed in Finland, as well as the theoretical background for court-connected mediation. The approaches can further be defined as narrow or broad, and the degree of facilitation and evaluation may vary (see e.g. Riskin 1996; Lowry 2004; Mayer 2004; Ervasti and Nylund 2014). The division is somewhat simplified but it clarifies discussions and it is pedagogically effective. The line between facilitative and evaluative mediation is, however, not always clear (Riskin 1996, 2003; Ervasti and Nylund 2014; Lowry 2004).

By definition a facilitative mediator's main task is to facilitate the negotiations and the problem solving process between the conflicting parties, here, the

\footnotetext{
${ }^{4}$ Since the Finnish court-connected family mediation is built around these two orientations, they frame the discussion on mediation in this article.
} 
parents (or other person having the custody). The facilitative mediator facilitates the communication between the parties and empowers them typically in a structured process to articulate their own interests, concerns, needs and solutions and to genuinely listen to and understand each other's. Facilitative mediation is usually interest-based. The focus is not on claims and legal definitions. A facilitative mediator does not direct the parties to a certain outcome and does not provide information. A facilitative mediator does not express his or her own opinion or suggestion for resolution in the matter and does not evaluate how a third person would resolve the case. The mediator does not evaluate the parties' views or proposals. The mediator is responsible for the process and the parties for the content and the outcome. The mediator supports the parties to find their own solutions. A facilitative mediator is neutral and objective, and the parties themselves carry the keys for resolution in their conflict (Riskin 1996; Mayer 2004; Ervasti and Nylund 2014, see also Lowry 2004).

The facilitative mediator "assumes that the parents are the most equipped agents to make good decisions about the needs of their children" and "even if parents want to make child-rearing decisions with which the facilitative mediator does not personally agree, his or her job is not to interfere" (Mayer 2004). The job for the facilitative mediator is to focus on helping the parents articulate and evaluate their own concerns (Mayer 2004).

In facilitative mediation it is up to the parties to decide what is the content of the discussions and if there is, for example, need for a legal discussion (see Adrian 2012; Ervasti and Nylund 2014). The mediator can support the parties to widen their perspectives and find alternatives (Ervasti and Nylund 2014). Also, new and creative outcomes are possible (Adrian and Mykland 2014). The purpose of facilitative mediation is for the parties to find a resolution that best serves their own and their common interests and they are satisfied with. In Finnish mediation research the baseline for mediation is facilitative (Ervasti and Nylund 2014).

How can then facilitative mediation promote the fulfilment of the child's legal rights and the best interests of the child? From the perspective of the best interests assessment, the first benefit is the individual and contextual discussions that aim to serve the parties' interests and needs. This promotes the individual, contextual and case-by-case solutions that are according to the CRC central in the best interests assessment. The other benefit is that the level of the conflict may diminish since the focus on is on the individual reasons, interest and needs behind the conflict. In this way, facilitative mediation may promote the parent's co-operation, turn the level and nature of their conflict more positive and spare the child from the conflict. This can protect the child's rights set forth in the UNCRC to e.g. the right to be protected from all forms of physical or mental violence, injury or abuse, neglect or negligent treatment, maltreatment or exploitation (article 19); the right to a standard of living adequate for the child's physical, mental, spiritual, moral and social development (article 27); and the to maintain personal relations and direct contact with both parents on a regular basis (article 9). When the negative conflict is erased from the child's growth environment, the child's right to rest and leisure, to engage in play and recreational activities (article 31) has better possibilities to be recognised and fulfilled as well. 
The way for a facilitative mediator to support the best interests of the child is to help the parents identify the information they need to make informed decisions and consider how they might obtain it. The substantive expertise of the mediator may help him or her ask useful questions and frame issues in a constructive and meaningful way, as well as address the possibility that mediation is not the best way to get the family's needs met (Mayer 2004). From the child law perspective, it would be thus important to raise awareness about the modern child law perspective among family mediators, as well as family lawyers, who often support the parents in the Finnish court-connected family mediation.

The facilitative orientation may be tested if the parties are agreeing to something illegal or are breaching a third person's rights, here, it would be the child's rights. If the mediator informs the parents that their view or agreement is against the law, the mediator is opting out of the facilitative role. The other option would be to keep on proposing questions to, reframing and challenging the parents on their views (Mayer 2004). The challenge in facilitative mediation from the child law perspective is the best interests assessment. Typically, the child is the common interest of the parents (Roberts 2008). However, the fulfilment of the child's legal rights is in the end dependent on the parents, their knowledge about the child's rights and what they find relevant. Many parents are facing questions relating the rights of the child in a separation situation for the first time (Lowry 2004), and they may not be aware of the child's rights and their application. This may be problematic also for the selfdetermination and the informed consent of the parents (Mayer 2004).

From the child law perspective, challenges arise if the child's rights are not part of the discussions, no best interests assessment is conducted and the child's right to participate is not considered. The mediator's neutrality and objectivity as well as confidentiality are limiting the role of the facilitative mediator. The mediator should focus on neutrally presenting questions to the parents, ease their communication and help them understand their own and each other's interest. Even though the facilitative approach may vary between highly structured, open ended and process or outcome oriented the mediator should not educate or advise the parents, provide information about the child's rights or conduct the best interests assessment (Mayer 2004). The facilitative mediator should not be the child's lawyer. ${ }^{5}$ Since the topics of discussion and the production of information are dependent on the parents, facilitative mediation may actually ignore the best interests assessment and the protection of the child's rights partly or completely.

\footnotetext{
${ }^{5}$ In Finland, the child is not a legal party in custody proceedings. The parents represent the child in these issues and no third-party child representatives to promote the child's legal rights in court emerge yet in Finland, see Tolonen (2015).
} 


\section{Evaluative Mediation Approach to the Best Interests of the Child}

Evaluative (or directive, see Riskin 2003) approach is another possible orientation, when systemising mediation models with problem-solving focus (Riskin 1996; Lowry 2004; Ervasti and Nylund 2014). The level of evaluative approach may vary between moderate and strong (Riskin 2003). The more evaluative the role and approach of the mediator, the more evaluative the mediation becomes (Lowry 2004; Mayer 2004; Ervasti and Nylund 2014).

Evaluative mediation is defined as an analytical process that focuses the mediator's attention on the substance of the conflict and what would be necessary in order to achieve a settlement (Lowry 2004). The evaluative orientation to mediation assumes that the mediator is capable of both facilitating the mediation process and making judgments about its contents. Evaluative mediator provides information to the parties and focuses on reaching an agreement. The parties can be directed to certain resolution that by the mediator is considered to the best or the right one. In addition to directions and providing information, the evaluative mediator can make evaluations. The evaluations can focus on (1) the parties' positions and claims, (2) how a third person such as a judge would resolve the questions and (3) giving or evaluating proposals for solution (Ervasti and Nylund 2014; Riskin 1996; Mackie 1997). Evaluative mediation is settlement and agreement focused and an effective way to reach an agreement as such (Riskin 1996; Lowry 2004).

The evaluative mediator has two different roles: the role of a facilitator and the role of an evaluator (Shienvold 2004). The evaluative mediator typically uses many facilitative techniques (Riskin 2003). The challenge in evaluative and directive approach is that it may endanger the neutrality of the mediator (Love 1997; Kovach and Love 1998; Ervasti and Nylund 2014). The evaluative mediator is not in the same manner limited by objectivity as is the facilitative mediator. The evaluative approach tends to undermine the focus on the process of interaction, communication, negotiation and decision making that is the main role of a facilitative mediator. If the parents see the mediator as an information provider, the mediator's role as a facilitator can become undermined (Mayer 2004).

How can then evaluative mediation promote the fulfilment of the child's legal rights and the best interests of the child? From the child law perspective, the benefit is that the mediator can provide the parents information about the child's rights and that a best interests assessment should be made. As mentioned above, many parents are facing the questions relating the rights of the child in a separated family for the first time, and they need information and expertise (Lowry 2004). The evaluative mediator can make sure that the rights of the child are not ignored. The evaluative mediator can also evaluate how the parents are supporting the rights of the child, direct them to focus on their child and provide information and proposals for solutions.

The evaluative mediator takes responsibility for the outcome and directs the parties to an agreement. Evaluative mediation can save the parties faces from not 
going too deep into the reasons behind the conflict and neutral proposals can be an excuse to agree. It might also open the parent's eyes to see the their positions differently. By this way evaluative mediation can support the family to move on rather quickly, avoid the court room and settle their case (Lowry 2004). Since the nature and level of conflicts are different for some families this might be the way out of the conflict. In this way the child's rights set forth in the UNCRC to e.g. maintain personal relations and direct contact with both parents on a regular basis (article 9) may be promoted.

The challenge with evaluative family mediation is that there is, however, a risk that the conflict remains if the reasons, needs and interest are not individually addressed and the agreement does not reach the real problems that should be agreed on. The evaluative approach can for some families be too agreement focused (Love 1997). If the conflict is ongoing and enduring the problem solving purpose and focus are narrow in that sense that they are not providing the parents tools for constructive engagement. The narrow approach may also ignore some severe problems in the family that infringe the rights of the child (such as family violence that needs special attention, see Nylund 2012, 2016). If the mediation does not reach the roots of the parent's conflict the parents may not be committed to their agreement, they may continue their fighting and are not able to co-operate, even though they have an agreement on paper. The child's rights set forth in the UNCRC to e.g. maintain personal relations and direct contact with both parents on a regular basis (article 9), to the enjoyment of the highest attainable standard of health (article 24), to rest and leisure, to engage in play and recreational activities (article 31), to not be subjected to degrading treatment or punishment (article 37), to be protected from all forms of physical or mental violence, injury or abuse, neglect or negligent treatment, maltreatment or exploitation (article 19) and to a standard of living adequate for the child's development (article 27) may be under risk. The same applies to families with problems of violence, since in quick and narrow focused mediation many problems may be ignored (Nylund 2016).

The mechanisms for evaluations may vary between instructions and suggestions, as well as between statements and questions and evaluations can be strategic (Lowry 2004). No commonly agreed mechanisms exist (Ervasti and Nylund 2014; Lowry 2004; Riskin 1996). One important question is on what information are the evaluations based on. Typically no evidence material is presented in mediation. The challenge is if the parents experience the mediator as an authority; the parents trust on the evaluations, the evaluations may be based on more or less general or standardised information, on narrow, inadequate or lacking material or even false information. This may also lead to competition between the parents if they are trying to affect the mediator's proposals and evaluations. The parents may also feel pressure under directive mediation, and they agree since they feel that they have to. The family does not necessarily share the mindset of the mediator as to what is relevant in mediation. The real and individual problems may be thus unsolved and the problems may remain. The mediator takes over the parent's conversation and their opportunity and responsibility to solve their problems (Problems in evaluations, see Ervasti and Nylund 2014; Taylor 2002; Lowry 2004; Menkel-Meadow 1996). 
The child's individual needs and hopes may be ignored especially if the child is not participating. The mediator's influence may lead to too quick and narrow closure and dissatisfaction to both result and the process (Lowry 2004).

Evaluative mediation orientation may ignore the individual assessment of the best interests of the child (article 3 of the UNCRC) if the focus is on general and standardised information relating to children. Evaluative approach might not lower the level of conflict and by this way may ignore the child's rights set forth in the UNCRC to e.g. maintain personal relations and direct contact with both parents on a regular basis (article 9), to the enjoyment of the highest attainable standard of health (article 24), to rest and leisure, to engage in play and recreational activities (article 31 ), to not be subjected to degrading treatment or punishment (article 37), to be protected from all forms of physical or mental violence, injury or abuse, neglect or negligent treatment, maltreatment or exploitation (article 19) and to a standard of living adequate for the child's development (article 27). Evaluative mediation may have a general or standardised approach to the child's right to participate, which is problematic especially if the participation right (article 12) is ignored. Evaluative approach may limit the parent's self-determination and the primary responsibility to decide over their children (article 18).

\section{Conclusion}

This article has focused on the best interests of the child in facilitative and evaluative mediation. From the child law perspective, the best interests of the child can be reached in mediation if the best interests assessment is conducted and all of the rights belonging to the child are taken into consideration, including the right to participate. In other situations, from the child law perspective, we have not reached the best interests of the child (Nieminen 2013).

The best interests of the child is, however, a complex and interdisciplinary concept. A lawyer and a psychologist, for example, see and understand the best interests of a child in mediation somewhat differently (see also Toivonen 2017). We need different tools to reach different elements of the whole. The legal perspective is one of the elements, and as described above, the best interests assessment provides a legal method - a legal checklist - to promote the best interests of the child. Standardised methods are seen as one tool to take the best interests of the child into account and to promote the child's legal security (Toivonen 2017; Kaldal 2012).

As discussed in this article facilitative and evaluative mediation orientations have somewhat different approaches to conflict resolution and, in this case, also to the child's rights. What is common for both approaches and mediation in general is that the parents are the ones who make the decisions. However, the mediator's role and approach affect the way the decisions are reached. The two mediation orientations were not developed to ensure the full and effective enjoyment of the rights of the child recognised in the UNCRC and the holistic development of the child. Thus the child law perspective and the best interests assessment require special attention in 
the traditional facilitative and evaluative mediation orientations. The child law approach creates an additional special element to facilitative and evaluative mediation.

Finnish court-connected family mediation is a combination of facilitative and evaluative mediation orientations and, in addition, the mediator is obliged to secure the best interests of the child. From a theoretical point of view, this seems to be a challenging combination. The Finnish mediator is firstly balancing between the two mediation orientations. Secondly, the mediator is balancing between the various definitions of the best interests of the child that in the Finnish court-connected family mediation is connected to (1) the National Act on Child Custody and Right of Access that represents the more traditional child law and not directly to the modern rightsbased child law approach and (2) the UNCRC to which Finland is committed to. From the perspective of this article, Finnish court-connected family mediation meets challenges with the best interests standard and needs further research. ${ }^{6}$

\section{References}

Adrian L (2012) Mellem retssag og rundbordssamtale: retsmægling i teori og praksis. Jurist- og Økonomforbundets Forlag, København

Adrian L, Mykland S (2014) Creativity in court-connected mediation: myth or reality? Negot J 30(4):421-439

Auvinen M (2006) Huoltoriidat tuomioistuimissa. Sosiaalitoimi selvittäjänä, sovittelijana, asiantuntijana. Suomalainen lakimiesyhdistys, Helsinki

Aaltonen AK (2000) Tuomari sovinnontekijänä perheoikeusasioissa. Lakimies 98(7-8):1320-1324

Aaltonen AK (2015) Huoltoriitojen sovittelu tuomioistuimessa. Kauppakamari, Helsinki

Bendiksen L, Haugli T (2014) Sentrale emner i barneretten. Universitetsforlaget, Oslo

Bush RAB, Folger JP (2005) The promise of mediation. the transformative approach to conflict. Jossey-Bass, San Francisco

CRC General Comment 12 (2009) Committee on the Rights of the Child. General comment No. 12 (2009): The right of the child to be heard, 12.2.2009

CRC General Comment 14 (2013) Committee on the Rights of the Child. General comment No. 14 (2013) on the right of the child to have his or her best interests taken as a primary consideration (article 3, para. 1), 29.5.2013

Ervasti K (2011) Tuomioistuinsovittelu Suomessa. Helsinki, Oikeuspoliittinen tutkimuslaitos

Ervasti K, Nylund A (2014) Konfliktinratkaisu ja sovittelu. Helsinki, Edita

Freeman M (2012a) Introduction. Law Child Stud Curr Legal Issues 14:1-9

Freeman M (2012b) Towards a sociology of children's rights. Law Child Stud Curr Legal Issues $14: 29-38$

Gottberg E (2006) Yksityisen ja julkisen rajapintoja. Lapsen läheissuhteet yksityisen ja julkisen rajapinnassa. Lakimies 104(7-8):1225-1239

Haavisto V (2018) Developing family mediation in Finland: the change process and practical outcomes. In: Nylund A, Ervasti K, Adrian L (eds) Nordic Mediation Research. Springer, Cham, pp 41-66

\footnotetext{
${ }^{6}$ The empirical qualitative data of my dissertation focuses on how mediators are conducting mediation and supporting the best interests of the child in practice. The data consist of observations and interviews.
} 
Hakalehto-Wainio S (2013) Uusi lapsioikeus. In: Husa J, Keskitalo P, Linna T, Tammi-Salminen E (eds) Oikeuden avantgarde. Juhlajulkaisu Juha Karhu 1953 - 6/4 - 2013. Talentum, Helsinki, pp 59-76

HE 114/2004 vp (2004) Hallituksen esitys eduskunnalle riita-asioiden sovittelua ja sovinnon vahvistamista yleisissä tuomioistuimissa koskevaksi lainsäädännöksi

Johnston J, Roseby V, Kuehnle K (2009) In the name of the child. A developmental approach to understanding and helping children of conflict and violent divorce. Springer, New York

Kaldal A (2012) Standardiserade metoder för att bedöma risk i ärenden om vårdnad, boende och umgänge. Juridisk Tidskrift 24(3):540-562

Kangas U (2013) Perhe- ja jäämistöoikeuden perusteet. Helsinki, Talentum

Karttunen R (2010) Isän ja äidin välissä. Lapsen kuulemisen psykologinen kehys huolto- ja tapaamisriidoissa. Tampere University Press, Tampere

Kovach K, Love L (1998) Mapping mediation: the risks of Riskin's Grid. Harv Negot Law Rev 3:71-110

Love LP (1997) The top ten reasons why mediators should not evaluate. Fla State Univ Law Rev 24:937-948

Lowry RL (2004) Evaluative mediation. In: Folberg J, Milne A, Salem P (eds) Divorce and family mediation. models, techniques, and applications. The Guilford Press, New York, pp 72-91

Mackie K (1997) Mediation futures. In: Macfarlane J (ed) Rethinking disputes: the mediation alternative. Cavendish, London, pp 371-379

McIntosh J (2000) Child-inclusive divorce mediation: report on a qualitative research study. Mediat Q 18(1):55-69

McIntosh J, Wells YD, Smyth BM, Long CM (2008) Child-focused and child-inclusive divorce mediation: comparative outcomes from a prospective study of postseparation adjustment. Family Court Rev 46(1):105-124

Mayer B (2004) Facilitative mediation. In: Folberg J, Milne A, Salem P (eds) Divorce and family mediation. models, techniques, and applications. Guilford Press, New York, pp 29-52

Menkel-Meadow C (1996) Is mediation the practice of law? Altern High Cost Litig 14:57-61

Mueller-Johnson K (2005) Supporting conflicted post-divorce parenting. In: Maclean M (ed) Family law and family values. Hart, Oxford

Nieminen L (1992) Objektista subjektiksi. Perus- ja ihmisoikeusjärjestelmän sukupuolisidonnaisuudesta. In: Turunen R (ed) Naisnäkökulmia oikeuteen. Gaudeamus, Helsinki, pp 58-84

Nieminen L (2013) Perus- ja ihmisoikeudet ja perhe. Helsinki, Talentum

Nolan-Haley JM (1999) Informed consent in mediation: a guiding principle for truly educated decisionmaking. Notre Dame Law Rev 74(3):775-840

Nylund A (2012) Barnefordelingssaker og familier med høyt konfliktnivå. Tidskrift for familierett, arverett og barnevernrettslige spørsmål 10(3-4):215-235

Nylund A (2016) Tilpasset mekling som konfliktløsningsmetode i konflikter om omsorgsorganisering. Tidskrift for familierett, arverett og barnevernrettslige spørsmål 12(2):106-124

OM 25/2013. Oikeusministeriön Mietintöjä ja lausuntoja 25/2013. Asiantuntija-avusteista huoltoriitojen sovittelua koskeva kokeilu käräjäoikeuksissa 1.1.2011-31.12.2013. Loppuraportti

Pajulammi H (2014) Lapsi, oikeus ja osallisuus. Helsinki, Talentum

Parkinson L (2011) Family mediation. Appropriate dispute resolution in a new family justice system. Family Law, Bristol

Parkinson P, Cashmore J (2008) The voice of a child in family law disputes. Oxford University Press, Oxford

Rejmer A (2003) Vårdnadstvister. En rättssociologisk studie av tingsrätts function vid handläggning av vårdnadskonflikter med utgångspunkt från barnets bästa. Lund Studies in Sociology of Law, Lund

Riskin L (1996) Understanding mediators' orientations, strategies, and techniques. Harv Negot Law Rev 1:7-51

Riskin L (2003) Decisionmaking in mediation: the new old grid and the new new grid system. Notre Dame Law Rev 79(1):1-54 
Roberts M (2008) Mediation in family disputes. Principles of practice. Ashgate, Aldershot

Salminen K, Ervasti K (2015) Tuomioistuinsovittelun yleistyminen ja tuomioistuimen tehtävät. Lakimies 113(5):591-612

Saposnek DT (2004) Working with children in mediation. In: Folberg J, Milne A, Salem P (eds) Divorce and family mediation. Models, techniques, and applications. The Guilford Press, New York, pp 155-179

Shienvold A (2004) Hybrid processes. In: Folberg J, Milne A, Salem P (eds) Divorce and family mediation. Models, techniques, and applications. The Guildford Press, New York, pp 112-126

Sinkkonen J (2011) Kiintymyssuhdenäkökulma vanhempien avo- tai avioeroon. In: Sinkkonen J, Kalland M (eds) Varhaislapsuuden tunnesiteet ja niiden suojeleminen. Helsinki, WSOYpro

Skjørten K (2005) Samlivsbrudd og barnefordeling. Gyldendal Akademisk, Oslo

Taylor A (2002) Family dispute resolution. Mediation theory and practice. Jossey-Bass, San Francisco

Toivonen V (2017) Lapsen oikeudet ja oikeusturva. Lastensuojeluasiat hallintotuomioistuimissa. Alma Talent, Helsinki

Tolonen H (2015) Lapsi, perhe ja tuomioistuin. Lapsen prosessuaalinen asema huolto- ja huostaanotto-oikeudenkäynneissä. Suomalainen lakimiesyhdistys, Helsinki

Welsh N (2004) Reconciling self-determination, coercion, and settlement in court-connected mediation. In: Folberg J, Milne A, Salem P (eds) Divorce and family mediation. Models, techniques, and applications. The Guilford Press, New York, pp 420-443

Open Access This chapter is licensed under the terms of the Creative Commons Attribution 4.0 International License (http://creativecommons.org/licenses/by/4.0/), which permits use, sharing, adaptation, distribution and reproduction in any medium or format, as long as you give appropriate credit to the original author(s) and the source, provide a link to the Creative Commons license and indicate if changes were made.

The images or other third party material in this chapter are included in the chapter's Creative Commons license, unless indicated otherwise in a credit line to the material. If material is not included in the chapter's Creative Commons license and your intended use is not permitted by statutory regulation or exceeds the permitted use, you will need to obtain permission directly from the copyright holder.

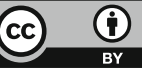

